\title{
Rhizobium hainanense sp. nov., Isolated from Tropical Legumes
}

\author{
WEN-XIN CHEN, ${ }^{*}$ ZHI-YUAN TAN, JUN-LIAN GAO, YING LI, AND EN-TAO WANG \\ Department of Microbiology, College of Biological Sciences, China Agricultural University, Beijing 100094, \\ People's Republic of China
}

\begin{abstract}
A fast-growing rhizobial group isolated from leguminous plants in Hainan Province, a tropical region of China, is proposed as a new Rhizobium species on the basis of 16S rRNA gene sequencing, DNA-DNA hybridization, and phenotypic characterization. This new species belongs to the phylogenetic branch which includes Rhizobium leguminosarum. We propose the name Rhizobium hainanense sp. nov. for this species. The strain CCBAU 57015 (I66) is the type strain; it has been deposited in the culture collection of Beijing Agricultural University, People's Republic of China.
\end{abstract}

Diversity in rhizobia nodulating tropical legumes has been revealed by many studies, and these bacteria belong to several bacterial genera and species. Many slow-growing strains isolated from tropical legumes belong to the genus Bradyrhizobium $(11,15)$. A unique group of strains inducing stem and root nodules on Sesbania rostrata, a tropical legume of Africa, constitute the genus Azorhizobium (8). Rhizobium tropici (18) and Rhizobium etli (22) were proposed for the rhizobia isolated from the common bean (Phaseolus vulgaris) and Leucaena leucocephala in the tropical region. Recently, Sinorhizobium saheli and Sinorhizobium teranga were proposed for some isolates from Acacia and Sesbania (6). Some other groups nodulating plants of the genera Acacia and Leucaena were identified by numerical taxonomy (33) and genetic analysis (13). In our previous research, some rhizobia were isolated from nodules of various species of leguminous plants, including trees, herbs, and vines growing in Hainan province, a tropical region of China, and were characterized by using numerical taxonomy and DNA-DNA hybridization (11). All slow-growing rhizobia among them were classified as Bradyrhizobium japonicum strains, while the fast-growing rhizobia from Hainan were diverse both in phenotypic and genetic aspects. Some strains belonged to previously described Rhizobium species; the others formed unique subgroups. Among them subgroup IV was distinguished from all previously described Rhizobium species by numerical taxonomy and by an analysis of DNA hybridization data. The 13 strains in this subgroup were isolated from 12 leguminous species classified in nine different genera (11). A partial 16S rRNA gene sequence from strain I66, the reference strain of subgroup IV, showed a close relationship with those of Rhizobium species but could not be used to separate subgroup IV from $R$. tropici $\mathrm{B}$, because the partial 16S rRNA gene sequence was identical to that of $R$. tropici B CIAT $899^{\mathrm{T}}(25)$. In order to determine the exact taxonomic position of subgroup IV, some further studies were performed, including full 16S rRNA gene (ribosomal DNA [rDNA]) sequencing, analysis of symbiotic performance with hosts for this subgroup and with selected hosts according to the guidance in the "Proposed Minimal Standards for the Description of New Genera and Species of Root- and Stem-Nodulating Bacteria" (12), and additional research on DNA relatedness between this group and $R$. tropici, $R$. etli, and Agrobacterium rhizogenes. The results of these studies led to a proposal for a new species, Rhizobium

* Corresponding author. Mailing address: Department of Microbiology, College of Biological Sciences, China Agricultural University, Beijing 100094, People's Republic of China. Phone: 86-10-62631854. Fax: 86-10-62582128. E-mail: wenxin@public.east.cn.net. hainanense, for this fast-growing Rhizobium group, which we describe here.

\section{MATERIALS AND METHODS}

Bacterial strains. Strains used in this study are listed in Table 1. The $R$. hainanense (subgroup IV) strains are fast-growing rhizobia isolated from the Hainan Province of China (11). The yeast mannitol agar (YMA) (24) medium was used for strain maintenance, and tryptone-yeast extract medium (1) was used for cell production. All strains were incubated at $28^{\circ} \mathrm{C}$.

DNA-DNA hybridization. Cells were grown and harvested by centrifugation. The pellets were washed twice with $10 \mathrm{mM}$ Tris- $\mathrm{HCl}$ ( $\mathrm{pH} \mathrm{7.0)}$. DNA was extracted by the method of Marmur (16). The initial-reassociation-rate method (7) was used for determining the percentage of DNA-DNA hybridization.

Amplification and cloning of 16S rDNA. The 16S rRNA genes were amplified in a $100-\mu l$ reaction mixture by using universal forward primer P1 $\left(5^{\prime}\right.$-CGggatc cAGAGTTTGATCCTGGCTCAGAACGAACGCT-3'; corresponding to positions 8 to 37 in Escherichia coli rDNA [2]) and universal reverse primer P6 (5'-CGggatccTACGGCTACCTTGTTACGACTTCACCCC-3'; corresponding to positions 1479 to 1506 ). The lowercase letters in the primer indicate the restriction site of Bam $\mathrm{HI}$. The protocol described by Chun and Goodfellow (5) and a PCR kit purchased from Promega Co. (Madison, Wis.) were used. Amplified $16 \mathrm{~S}$ rDNA was purified from $0.8 \%$ low-melting-point agarose gel by using the method of Wieslander (27). Purified rDNA and plasmid pUC18 vector were cut with $\mathrm{BamHI}$ and ligated at $16^{\circ} \mathrm{C}$ for $16 \mathrm{~h}$. Ligated plasmids were transformed into $E$. coli $\mathrm{DH} 5 \alpha$, and transformants were selected on the basis of the results of the blue-white screening procedure $(21,27)$.

DNA sequencing. Plasmids containing 16S rDNA were extracted and purified according to the methods of Tiesman and Rizzino (23). Purified plasmids were sequenced by using the fmol DNA sequencing system (Promega Co.) according to the manufacturer's instructions. Six primers for sequencing were selected based on the work of Yanagi and Yamasato (30) and Willems and Collins (28). They were P1 and P6 and an additional four primers, P2 through P5, with, respectively, the following sequences ( $E$. coli numbering system): $5^{\prime}$-GCTAGT TGGTGGGGTAA-3' (positions 247 to 263), 5'-CGTGCCAGCAGCCGCGGT $-3^{\prime}$ (positions 514 to 531), 5'-TAGATACCCTGGTAGTCC-3' (positions 799 to 806), and 5' -CCGCAACGAGCGCAACCC-3' (positions 1097 to 1115 ).

Phylogenetic analysis. The generated rDNA sequences and the sequences for reference strains obtained from the EMBL, GenBank, and DDBJ data libraries were resampled 1,000 times for a bootstrap analysis (9) using the SEQBOOT program (PHYLIP, version 3.572c [10]). Deletions and insertions of more than one base length were counted as one change. Pairwise similarity values were calculated and converted to a distance matrix with the Jukes-Cantor coefficient in the DNADIST program. Phylogenetic trees were produced by the neighborjoining method in the NEIGHBOR program, and a consensus tree was generated by the majority-rule and strict-consensus tree program (PHYLIP, version $3.572 \mathrm{c})$.

Symbiotic performance test. Glass tubes ( 40 by $400 \mathrm{~mm}$ ) half filled with vermiculite were used as seedling containers, and the inoculating methods described by Vincent (24) were used. The temperature in the greenhouse was kept at $28^{\circ} \mathrm{C}$ during the day and at $12^{\circ} \mathrm{C}$ during the night, with illumination of 10,000 to $20,000 \mathrm{~lx}$ for $14 \mathrm{~h}$ a day.

Nucleotide sequence accession number. The $16 \mathrm{~S}$ rDNA sequence determined in this study has been deposited in the EMBL and GenBank nucleotide sequence databases under accession number U71078.

\section{RESULTS AND DISCUSSION}

Analysis of DNA hybridization. DNA-DNA hybridization is the standard arbiter for the designation of species, and the 
TABLE 1. List of bacterial strains examined

\begin{tabular}{|c|c|c|c|}
\hline Strain & Host & Origin & Source ${ }^{a}$ \\
\hline M. loti NZP $2213^{\mathrm{T}}$ & L. comiculatus & New Zealand & NZP \\
\hline S. meliloti USDA $1002^{\mathrm{T}}$ & M. sativa & United States & USDA \\
\hline $\begin{array}{l}\text { R. leguminosarum } \\
\text { USDA } 2370^{\mathrm{T}}\end{array}$ & & United States & USDA \\
\hline R. tropici B BR 853 & L. leucocephala & & CNPS \\
\hline R. tropici B BR 847 & L. leucocephala & & CNPS \\
\hline R. tropici B CIAT $899^{\mathrm{T}}$ & $P$. vulgaris & & CNPBS \\
\hline R. tropici A CFN 299 & P. vulgaris & & CNPBS \\
\hline R. tropici A C-05-I & P. vulgaris & & CNPBS \\
\hline R. etli CFN $42^{\mathrm{T}}$ & P. vulgaris & & CNPBS \\
\hline R. galegae HAMBI $540^{\mathrm{T}}$ & Galega orientalis & Finland & HAMBI \\
\hline M. huakuii CCBAU $2609^{\mathrm{T}}$ & A. sinicus & Nanjing, China & CCBAL \\
\hline S. fredii USDA $205^{\mathrm{T}}$ & Glycine soja & Henan, China & USDA \\
\hline M. tianshanense $\mathrm{A}-1 \mathrm{BS}^{\mathrm{T}}$ & $\begin{array}{l}\text { Glycyrrhiza pal- } \\
\text { lidiflora }\end{array}$ & Xinjiang, China & CCBAL \\
\hline B. japonicum USDA $6^{\mathrm{T}}$ & G. $\max$ & United States & USDA \\
\hline $\begin{array}{l}\text { R. hainanense } 166^{\mathrm{T}} \\
\quad(\text { CCBAU 57015) }\end{array}$ & D. sinuatum & Hainan, China & CCBAL \\
\hline A. rhizogenes IAM $13570^{\mathrm{T}}$ & & Japan & IAM \\
\hline
\end{tabular}

${ }^{a}$ NZP, Division of Scientific and Industrial Research, Palmerston North, New Zealand; USDA, Beltsville Rhizobium Culture Collection, Beltsville Agricultural Research Center, Beltsville. Md.; CNPBS, Centro National de Pesquisa em Biologia do solo, Iseropedica 23851, Rio de Janeiro, Brazil; HAMBI, Culture Collection of the Department of Microbiology, University of Helsinki, Helsinki, Finland; CCBAU, Culture Collection of Beijing Agricultural University, Beijing, China; IAM, Institute of Applied Microbiology, The University of Tokyo, Tokyo, Japan.

criterion for a species is $\geq 70 \%$ DNA-DNA relatedness (26). The values of DNA-DNA relatedness within subgroup IV were found to be $>70 \%$ and those between strain I66 and type strains of other rhizobial species were found to be very low in our previous studies (11). Since the same phylogenetic branch contained $R$. tropici A, $R$. tropici $\mathrm{B}, R$. etli, and $A$. rhizogenes, we studied DNA-DNA relatedness between strain $166^{\mathbf{T}}$ and type strains for these three groups. The results show that the DNADNA relatedness between strain $166^{\mathrm{T}}$ and $R$. tropici A CFN $299, R$. tropici B CIAT $899^{\mathrm{T}}, R$. etli CFN $42^{\mathrm{T}}$, and $A$. rhizogenes IAM $13570^{\mathrm{T}}$ were $23.4,24.8,19.2$, and $12.7 \%$, respectively. This showed that subgroup IV was distinct from $R$. tropici $\mathrm{A}, R$. tropici $\mathrm{B}, R$. etli, and $A$. rhizogenes.

16S rRNA gene sequence analysis. The variable fragment of 16S rDNA amplified by using primers $\mathrm{Y} 1$ and $\mathrm{Y} 2$ (32) on DNA from strain I66 was sequenced in our previous research (25). The sequence of that fragment in the full sequence obtained in this research is identical with the partial sequencing result (25). An unrooted phylogenetic tree (Fig. 1) was generated by the neighbor-joining method (10) based on a comparison of the 16S rRNA gene sequences of all available rhizobial species and related bacteria. The rhizobial species formed six clusters (Fig. 1), which were similar to those reported by previous workers $(17,19,20,31)$. These included Sinorhizobium, Mesorhizobium (14), Rhizobium galegae-Agrobacterium tumefaciens and Agrobacterium vitis, Rhizobium-A. rhizogenes, Bradyrhizobium, and Azorhizobium. The phylogenetic relatedness in each cluster and among the clusters had been discussed elsewhere $(6,8,17$, $19,20,29,31)$. Strain $\mathrm{I}^{\mathrm{T}} 6^{\mathrm{T}}$ falls in the Rhizobium- $A$. rhizogenes cluster (Fig. 1), which consisted of $R$. etli, R. leguminosarum, $R$. tropici A, $R$. tropici $\mathrm{B}$, and $A$. rhizogenes, and was most closely related to $R$. leguminosarum (the similarity value was $96.9 \%$ ). This clearly showed that subgroup IV belonged phylogenetically to the genus Rhizobium. Although the phylogenetic position of subgroup IV was not found to be distinct from that of $R$. tropici B by analysis of the partial 16S rRNA sequences (25), it was distinguished clearly from the $R$. tropici $\mathrm{B}$ position by the full sequence of its $16 \mathrm{~S}$ rRNA genes. Similar situations occurred with $R$. galegae $(29,30)$. So it seems that the partial sequencing of $16 \mathrm{~S}$ rDNA has limited value in determining phylogenetic relationships among rhizobial species.

Diagnostic tests. We selected the differential features between subgroup IV and other species from the same phylogenetic branch from published data and confirmed them by testing the type strains. The results are shown in Table 2 . These results show that phenotypic features can be used to distinguish subgroup IV from phylogenetically related bacteria.

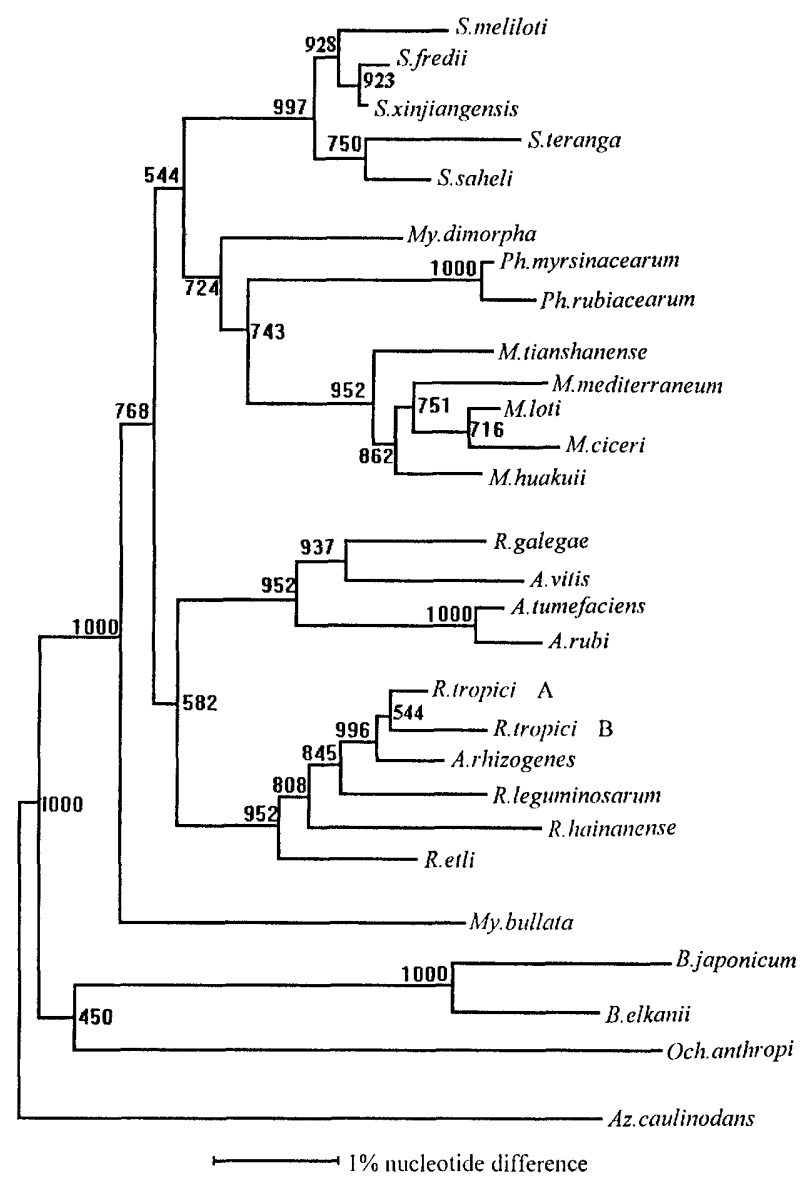

FIG. 1. Unrooted phylogenetic tree, showing the position of $R$. hainanense within the genus Rhizobium. Abbreviations: My, Mycoplana; S, Sinorhizobium; Och, Ochrobactrum; A, Agrobacterium; Az, Azorhizobium; Ph, Phyllobacterium B, Bradyrhizobium; M, Mesorhizobium. The accession numbers of the $16 \mathrm{~S}$ rRNA gene sequences are as follows: Agrobacterium rubi LMG 156, X67228; $A$. tumefaciens LMG 196, X67223; $A$ rhizogenes LMG 152, X67224; $A$ vitis LMG 8750 , X67225; $S$. fredii LMG 6217, X67231; $S$. meliloti LMG 6133, X67222; Sinorhizobium xinjiangensis IAM 14142, D12796; $S$. saheli LMG 7837, X68390; S. teranga LMG 6463, X68387; $R$. galegae LMG 6215, X67226; $R$. leguminosarum LMG 8820, X67227; $M$. loti LMG 6125, X67229; $R$. tropici B LMG 9518, X67234; $R$. tropici A LMG 9517, X67233; $R$. etli ATCC 14483, U47303; M. huakuii IAM 14158, D12791; Mesorhizobium ciceri UPM-Ca7, U07934; Mesorhizobium mediterraneum UPM-Ca36, L38825; B. japonicum LMG 6138, X66024; Phyllobacterium myrsinacearum IAM 13584, D12789; Phyllobacterium rubiacearum IAM 13587, D12790; Mycoplana dimorpha IAM 13154, D12786; Mycoplana bullata IAM 13153, D12785; Ochrobactnum anthropi IAM 14119, D12794; Azorhizobium caulinodans LMG 6465, X67221; Bradyrhizobium elkanii ATCC 49852, U35000; $M$. tianshanense A-1BS, U71079; $R$. hainanense I66 ${ }^{\mathrm{T}}$, U71078. In the above strain designations, the following abbreviations are used: LMG, Culture Collection Laboratorium voor Microbiologie, Universiteit Gent, Ghent, Belgium; IAM, Institute of Applied Microbiology, The University of Tokyo, Tokyo, Japan; ATCC, American Type Culture Collection, Rockville, Md. D, DDBJ accession numbers. 
TABLE 2. Distinctive features of $R$. hainanense and related species in the genus Rhizobium

\begin{tabular}{|c|c|c|c|c|c|}
\hline \multirow[b]{2}{*}{ Characteristic } & \multicolumn{5}{|c|}{ Ability of indicated strain to grow ${ }^{a}$} \\
\hline & $\begin{array}{l}\text { R. leguminosarum } \\
\text { USDA } 2370^{\mathrm{T}}\end{array}$ & $\begin{array}{c}\text { R. etli } \\
\text { CFN } 42^{\mathrm{T}}\end{array}$ & $\begin{array}{l}\text { R. tropici A } \\
\text { CFN } 299\end{array}$ & $\begin{array}{l}\text { R. tropici B } \\
\text { CIAT } 899^{\mathrm{T}}\end{array}$ & $\begin{array}{l}\text { R. hainanense } \\
\mathrm{I} 66^{\mathrm{T}}\end{array}$ \\
\hline \multicolumn{6}{|l|}{ Utilization of sole carbon sources } \\
\hline$\alpha$-Alanine & + & + & + & - & - \\
\hline L-Aspartate & + & - & + & + & + \\
\hline Glucosamine- $\mathrm{HCl}$ & - & + & + & + & + \\
\hline DL-Cystine & - & - & - & + & + \\
\hline Erythritol & + & - & - & + & + \\
\hline$\alpha$-Ketoglutarate & - & - & - & + & + \\
\hline L-Leucine & - & - & - & - & + \\
\hline L-Lysine & - & - & - & + & - \\
\hline L-Ornithine $\mathrm{HCl}$ & - & + & + & - & + \\
\hline L-Phenylalanine & - & - & - & + & - \\
\hline L-Tryptophan & - & - & - & + & - \\
\hline Growth in $2 \% \mathrm{NaCl}$ & - & - & - & + & + \\
\hline Growth at $40^{\circ} \mathrm{C}$ & - & - & - & + & + \\
\hline Growth at pH 5 & - & - & + & + & + \\
\hline Growth at $\mathrm{pH} 10$ & - & - & + & + & + \\
\hline \multicolumn{6}{|l|}{ Resistance to antibiotics } \\
\hline Terramycin $(50 \mu \mathrm{g} / \mathrm{ml})$ & - & - & - & + & - \\
\hline Kanamycin $(5 \mu \mathrm{g} / \mathrm{ml})$ & - & - & - & - & + \\
\hline Chloramphenicol $(100 \mu \mathrm{g} / \mathrm{ml})$ & - & - & - & + & - \\
\hline
\end{tabular}

$a+$, strain can grow; - , strain cannot grow.

Symbiotic performance. In accordance with the suggestion of Graham et al. (12), the nodule-forming abilities of strain I $66^{\mathrm{T}}$ were checked on selected leguminous species, including Astragalus sinicus and Glycyrrhiza uralensis, which were representative hosts for Mesorhizobium huakuii $(4,14)$ and Mesorhizobium tianshanense $(3,14)$, respectively. Hosts of all 13 strains in subgroup IV were also tested. Nodulating abilities of type cultures for other rhizobial species on Desmodium sinuatum, the original host of strain $166^{\mathrm{T}}$, were also checked. Results showed that strain $\mathrm{I} 66^{\mathrm{T}}$ could only nodulate on its original host, $D$. sinuatum, and not on the hosts of other members of subgroup IV, e.g., Stylosanthes guyanansis, Centrosema pubescens, Desmodium triquetrum, Desmodium gyroides, Desmodium heterophyllum, Tephrosia candida, Acacia sinuata, Zornia diphylla, and Macroptilium lathyroides. This meant that the hosts of members of subgroup IV were not in a single crossinoculation group. Maybe they each have a different host range. Strain $166^{\mathrm{T}}$ could not nodulate Medicago sativa, Pium sativum, P. vulgaris, Trifolium repens, Lotus corniculatus, Glycine max, L. leucocephala, Macroptilium atropurpureum, Galega officinalis, A. sinicus, or $G$. uralensis, but it could nodulate Vigna unguiculata, which was a universal host for many different rhizobia. The type cultures of strains $R$. leguminosarum USDA 2370, Sinorhizobium meliloti USDA 1002, Mesorhizobium loti NZP 2213, $R$. tropici CIAT 899, M. huakuii CCBAU 2609, Sinorhizobium fredii USDA 205, and B. japonicum USDA 6 could not nodulate $D$. sinuatum. Based on the above studies and on previous numerical taxonomy and DNA-DNA hybridization (11), we propose that subgroup IV of Hainan fast-growing rhizobia is a new species, $R$. hainanense.

Description of $\boldsymbol{R}$. hainanense sp. nov. Rhizobium hainanense (hai.nan.ense ${ }^{1}$ M.L. adj. Hainan, name of a province of China; rhizobia isolated from Hainan Province). Aerobic, gram-negative, nonsporeforming rods that are 0.25 to 0.5 by 0.5 to 2.0 $\mu \mathrm{m}$. Motile by means of a single polar flagellum. Optimum temperature 25 to $30^{\circ} \mathrm{C}$ and can grow at $40^{\circ} \mathrm{C}$. Optimum pH 6 to 8 and can grow at pH 5 to 10 . Generation time is 2 to $4 \mathrm{~h}$ in YMA medium. Colonies in YMA are circular, opaque, and convex and have a creamy color. They are usually 1.5 to $2.5 \mathrm{~mm}$ in diameter after 3 days of incubation on YMA and produce acid. Arabinose, erythritol, fructose, glucose, inositol, lactose, maltose, melibiose, raffinose, rhamnose, D-ribose, sodium citrate, sodium succinate, sucrose, trehalose, turanose, xylose, DL-asparagine, and L-histidine can be used by these bacteria as the sole carbon and energy source for growth. Calcium malonate, ferulic acid, melezitose, sodium acetate, sodium hippurate, galactose, sorbose, vanillic acid, $\beta$-alanine, and glycine cannot be used. L-Alanine, DL-arginine, L-asparagine, DL-citrulline, DL-cystine, D-glutamic acid, L-glutamic acid, glycine, L-histidine, L-leucine, DL-ornithine, L-proline, L-serine, L-threonine, L-tryptophan, and L-valine can be used as the sole nitrogen source, but D-valine cannot be used. The other characteristics are as indicated in Table 2. Strains in this species were isolated from nodules of $S$. guyanansis, C. pubescens, D. triquetrum, $D$. gyroides, $D$. sinuatum, $D$. heterophyllum, $T$. candida A. sinuata, Arachis hypogaea, Z. diphylla, Uraria crinita, and $M$. Lathyroides. The $\mathrm{G}+\mathrm{C}$ moles percent content of the DNA is 59 to 63. The type strain is I66 (CCBAU 57015). Its generation time is $2 \mathrm{~h}$ on YMB medium (24). The $\mathrm{G}+\mathrm{C}$ moles percent content of its DNA is $61\left(T_{m}\right)$.

\section{ACKNOWLEDGMENTS}

We thank E. Martinez-Romero for kindly reading the manuscript.

This work was supported by the National Natural Science Foundation of China.

\section{REFERENCES}

1. Beringer, J. E. 1974. R factor transfer in Rhizobium leguminosarum. J. Gen. Microbiol. 84:188-198.

2. Brosius, J., M. L. Palmer, P. J. Kennedy, and H. F. Noller. 1978. Complete nucleotide sequence of a $16 \mathrm{~S}$ ribosomal RNA gene from Escherichia coli. Proc. Natl. Acad. Sci. USA 75:4801-4805.

3. Chen, W., E. Wang, S. Wang, Y. Li, X. Chen, and Y. Li. 1995. Characteristics of Rhizobium tianshanense sp. nov., a moderately and slowly growing root nodule bacterium isolated from an arid saline environment in Xinjiang, People's Republic of China. Int. J. Syst. Bacteriol. 45:153-159.

4. Chen, W. X., G. S. Li, Y. L. Qi, E. T. Wang, H. L. Yuan, and J. L. Li. 1991 Rhizobium huakuii sp. nov. isolated from the root nodules of Astragalus 
sinicus. Int. J. Syst. Bacteriol. 41:275-280.

5. Chun, J., and M. Goodfellow. 1995. A phylogenetic analysis of the genus Nocardia with 16S rRNA gene sequences. Int. J. Syst. Bacteriol. 45:240-245.

6. De Lajudie, P., A. Willems, B. Pot, D. Dewettinck, G. Maestrojuan, M. Neyra, M. D. Collins, B. Dreyfus, K. Kersters, and M. Gillis. 1994. Polyphasic taxonomy of rhizobia: emendation of the genus Sinorhizobium and description of Sinorhizobium meliloti comb. nov., Sinorhizobium saheli sp. nov., and Sinorhizobium teranga sp. nov. Int. J. Syst. Bacteriol. 44:715-733.

7. De Ley, J., H. Cattoir, and A. Reynaerts. 1970. The quantitative measurement of DNA hybridization from renaturation rates. Eur. J. Biochem. 12: $133-142$.

8. Dreyfus, B., J. L. Garcia, and M. Gillis. 1988. Characterization of Azorhizobium cautinodans gen. nov., sp. nov., a stem-nodulating nitrogen-fixing bacterium isolated from Sesbania rostrata. Int. J. Syst. Bacteriol. 38:89-98.

9. Felsenstein, J. 1985. Confidence limits on phylogenies: an approach using the bootstrap. Evolution 39:783-791.

10. Felsenstein, J. 1993. PHYLIP-(Phylogeny Inference Package), version 3.572c. Department of Genetics, University of Washington, Seattle, Wash.

11. Gao, J. L., J. G. Sun, Y. Li, E. T. Wang, and W. X. Chen. 1994. Numerica taxonomy and DNA relatedness of tropical rhizobia isolated from Hainan Province, China. Int. J. Syst. Bacteriol. 44:151-158.

12. Graham, P. H., M. J. Sadowsky, H. H. Keyser, Y. M. Barnet, R. S. Bradley, J. E. Cooper, J. De Ley, B. D. W. Jarvis, E. B. Roslycky, B. W. Strijdom, and J. P. W. Young. 1991. Proposed minimal standards for the description of new genera and species of root- and stem-nodulating bacteria. Int. J. Syst. Bacteriol. 41:582-587.

13. Jarvis, B. D. W. 1983. Genetic diversity of Rhizobium strains which nodulate Leucaena leucocephala. Curr. Microbiol. 8:153-158.

14. Jarvis, B. D. W., P. Van Berkum, W. X. Chen, S. M. Nour, M. P. Fernandez J. C. Cleyet-Marel, and M. Gillis. 1997. Transfer of Rhizobium loti, Rhizobium huakuii, Rhizobium ciceri, Rhizobium mediterraneum, and Rhizobium tianshanense to Mesorhizobium gen. nov. Int. J. Syst. Bacteriol. 47:895-898.

15. Jordan, D. C. 1984 . Family III. Rhizobiaceae Conn 1938 , 321 AL, p. 234-244. In N. R. Krieg and J. G. Holt (ed.), Bergey's manual of systematic bacteriology, vol. 1. Williams and Wilkins Co., Baltimore, Md.

16. Marmur, J. 1961. A procedure for the isolation of deoxyribonucleic acid from microorganisms. J. Mol. Biol. 3:208-218.

17. Martinez-Romero, E. 1994. Recent developments in Rhizobium taxonomy. Plant Soil 161:11-20.

18. Martinez-Romero, E., L. Segovia, F. Martins, A. A. Franco, P. Graham, and M. A. Pardo. 1991. Rhizobium tropici, a novel species nodulating Phaseolus vulgaris L. beans and Leucaena sp. trees. Int. J. Syst. Bacteriol. 41:417-426.

19. Martinez-Romero, E., and J. Caballero-Mellado. 1996. Rhizobium phylogenies and bacterial genetic diversity. Crit. Rev. Plant Sci. 15:113-140.
20. Nour, S. M., J.-C. Cleyet-Marel, P. Normand, and M. P. Fernandez. 1995 Genomic heterogeneity of strains nodulating chickpeas (Cicer arietinum $\mathbf{L}$.) and description of Rhizobium mediterraneum sp. nov. Int. J. Syst. Bacteriol. 45:640-648.

21. Sambrook, J., E. F. Fritsch, and T. Maniatis. 1989. Molecular cloning: a laboratory manual, 2nd ed., p. 4.21-4.43. Cold Spring Harbor Laboratory Press, Cold Spring Harbor, N.Y.

22. Segovia, L., J. P. W. Young, and E. Martinez-Romero. 1993. Reclassification of American Rhizobium leguminosarum biovar Phaseoli type I strains as Rhizobium etli sp. nov. Int. J. Syst. Bacteriol. 43:374-377.

23. Tiesman, J., and A. Rizzino. 1991. A rapid and reliable method for the purification of high-quality plasmid DNA for double strand sequencing. BioTechniques 10:319-328.

24. Vincent, J. M. 1970. A manual for the practical study of root nodule bacteria, p. 3-4. Blackwell Scientific Publications, Ltd., Oxford, United Kingdom.

25. Wang, E. T., Y. B. Li, and W. X. Chen. 1994. Partial 16S rRNA gene sequencing of Hainan fast-growing rhizobium strain I66 by PCR. Acta Microbiol. Sinica 34:248-252. (In Chinese.)

26. Wayne, L. G., D. J. Brenner, R. R. Colwell, P. A. D. Grimont, O. Kandler, M. I. Krichevsky, L. H. Moore, W. E. C. Moore, R. G. E. Murray, E Stackebrandt, M. P. Starr, and H. G. Truper. 1987. Report of the ad hoc committee on reconciliation of approaches to bacterial systematics. Int. J. Syst. Bacteriol. 37:463-464.

27. Wieslander, L. 1979. A simple method to recover intact high molecular weight RNA and DNA after electrophoretic separation in low melting temperature agarose gels. Anal. Biochem. 98:305.

28. Willems, A., and M. D. Collins. 1992. Evidence for a close genealogical relationship between Afipia, the causal organism of cat scratch disease, Bradyrhizobium japonicum and Blastobacter denitrificans. FEMS Microbiol. Lett. 96:241-246.

29. Willems, A., and M. D. Collins. 1993. Phylogenetic analysis of rhizobia and agrobacteria based on 16S rRNA gene sequences. Int. J. Syst. Bacteriol. 43:305-313.

30. Yanagi, M., and K. Yamasato. 1993. Phylogenetic analysis of the family Rhizobiaceae and related bacteria by sequencing of 16S rRNA gene using PCR and DNA sequencer. FEMS Microbiol. Lett. 107:115-120.

31. Young, J. P. W., and K. E. Haukka. 1996. Diversity and phylogeny of rhizobia. New Phytol. 133:87-94.

32. Young, J. P. W., H. L. Downer, and B. D. Eardly. 1991. Phylogeny of the phototropic Rhizobium strain BTAil by polymerase chain reaction-based sequencing of a 16S rRNA gene segment. J. Bacteriol. 173:2271-2277.

33. Zhang, X., R. Harper, M. Karsisto, and K. Lindström. 1991. Diversity of Rhizobium bacteria isolated from the root nodules of leguminous trees. Int. J. Syst. Bacteriol. 41:104-113. 